\title{
Halal antimicrobials in food: A review on prospects and challenges of antimicrobials from animal sources
}

\author{
Muhamad Shirwan Abdullah Sani ${ }^{1,2 *}$, Mohammad Aizat Jamaludin ${ }^{1,2}$, Nurhidayu Al-Saari ${ }^{1,2}$, Azman Azid ${ }^{3}$, Nur \\ Syatirah Noor Azri ${ }^{4}$ \\ ${ }^{1}$ International Institute for Halal Research and Training, Level 3, KICT Building, International Islamic University \\ Malaysia, Jalan Gombak, 53100 Kuala Lumpur, Malaysia \\ ${ }^{2}$ Konsortium Institut Halal IPT Malaysia, Ministry of Higher Education, Block E8, Complex E, Federal \\ Government Administrative Centre, 62604 Putrajaya, Malaysia \\ ${ }^{3}$ Faculty Bioresources and Food Industry, Universiti Sultan Zainal Abidin (UniSZA) \\ ${ }^{4}$ Department of Biomedical Sciences, Kulliyyah of Allied Health Sciences, International Islamic University \\ Malaysia, 25200 Kuantan, Pahang Darul Makmur \\ *Corresponding author: Muhamad Shirwan Abdullah Sani, International Institute for Halal Research and Training \\ (INHART), Level 3, KICT Building, International Islamic University Malaysia (IIUM), Jalan Gombak, 53100, \\ Selangor, Malaysia; shirwansany@iium.edu.my
}

\begin{abstract}
Food antimicrobial agents (FAA) provide the first food defence system against pathogens for processed food products. In addition, they function as an antioxidant in preventing colour and taste changes for food safety and quality. Muslim consumers are concerned about the source of FAA which may contain non-permissible ingredients according to Islam including pig and unslaughtered permissible animal sources. They also raise concerns about the increasing risk of toxicity when the FAA is consumed and the possibility of the FAA rendering organoleptic effect on the food. The application of the FAA protects the food from microbial contamination and indirectly combats emerging devastating diseases. Hence, halal FAA (HFAA) can be introduced so that Muslim consumers can accept FAA usage. Generally, HFAA is categorised according to ingredient sources such as animal, plant, bacteria, or synthetic origins. There are doubts on the halal status of animal-origin FAA as the source might be originating from pig, unslaughtered animal, human, or origins which are filthy. The animalorigin FAA shows strong antimicrobial properties against Gram-positive and negative pathogens, as well as toxicity and organoleptic issues. Thus, the FAA should be used within the allowable range. HFAA has become one of the most studied FAAs due to these issues. Many HFAAs are produced from animals without the full verification of halal status. This review presents an overview of the origins and challenges of HFAA production. Furthermore, this study also highlights how FAA could be verified as halal which is the theme of future research in HFAA development.
\end{abstract}

Keywords: Halal; food antimicrobial agents; Generally recognised as safe (GRAS)

Received: $18^{\text {th }}$ February 2020

Accepted: $22^{\text {nd }}$ August 2020

Published Online: $22^{\text {nd }}$ September 2020
Citation: Abdullah Sani MS, Jamaludin MA, AlSaari N, et al. Halal antimicrobials in food: A review on prospects and challenges of antimicrobials from animal sources. J Halal Ind Serv 2020; 3(1): a0000113. https://doi.org/10.36877/jhis.a0000113 


\section{Introduction}

Islam has outlined the guide to life for Muslims, including the need to find halal and Toyyib food. Halal food is defined as permissible and lawful for consumption according to the al-Quran and al-Sunnah (Aziz, Musa \& Rahman, 2016). In this context, the food should be free from dirt or contamination of haram (prohibited) resources such as pork and unslaughtered animals. Toyyib in food refers to hygienic and nutritious food including the quality of taste, smell, and colour (Hashim \& Shariff, 2016). Consumable foods such as dairy products, seafood, raw meat, and semi-processed meat have a short shelf life that can be easily contaminated with bacteria-causing diseases; thus, there is the importance of exploiting the concept of toyyiban.

Food operators should follow good hygiene practice (GHP) and good manufacturing practice (GMP) to avoid food spoilage. These practices focus on safety and hygiene requirements in food handling (Błaszczyk, 2019). The implementation of these practices and halal assurance system (HAS) in the food supply chain can enhance the quality and safety of food products (Department of Standards Malaysia, 2019). However, the practices do not minimise the incidence of food spoilage and inhibit the growth of foodborne pathogens. Therefore, food preservation is used to inhibit bacterial growth while maintaining food nutrients and preventing food damage from unpleasant odour and colour changes. Boiling, cooling, freezing, pasteurisation, hydration, pickling, and traditional preservation are among the popular preservation processes. Some of the modern preservation techniques include nuclear radiation and modified packaging methods such as vacuum packaging. Besides that, antimicrobial agents function as control measure tools in food manufacturing.

Food antimicrobial agents (FAA) are commonly used in the product formulation stage or during the food production process as food additives reduce or eliminate food spoilage and pathogens. Muslim consumers are concerned about the source of FAA that may contain nonpermissible ingredients according to Islam besides increasing the risk of toxicity when being consumed. FAA might negatively render the organoleptic effect on the food. Generally, food including FAA is classified as halal according to ingredient sources like animal, plant, bacteria, or synthetic origins. Antimicrobials of animal-origins are the biggest challenge for the halal concept of HFAA because there are doubts on animal-origin FAA that might originate from pig, unslaughtered animals, human, or origins which are filthy. Some examples of FAA are AP originating from bovine (Palmieri et al., 2018) and lactoperoxidase from pigs for human consumption (Pisoschi et al., 2018). However, for their business applications, a number of manufacturers have falsely claimed the FAA origin and this issue has then caused concern to certain consumer groups such as vegetarians (Mutalib et al., 2015), Jews (Romi Mukherjee, 2014) and Muslims (Department of Standards Malaysia, 2019). The false claim has impaired HFAA integrity where HFAA origin is not correctly reported (Soon et al., 2017) and can lead to the consumer exposing themselves to diseases such as bovine spongiform encephalopathy 
or mad cow disease due to bovine-originated food (Azilawati et al., 2015). As a result, HFAA from animals is scrutinised for the Malaysian halal certification.

This review highlights the importance of incorporating halal and toyyiban concepts when developing halal food antimicrobials from animal sources. The paper presents the challenges of the current HFAA application regarding its halal status and prospects of HFAA. Finally, the paper discusses various aspects that should be considered before introducing halal and toyyiban food antimicrobials in processing food products.

\section{Disucussion}

\section{Food Antimicrobial Agents}

In general, FAA is the additives used in food processing to prevent biological deterioration which is classified as preservatives. The U.S. Food and Drug Administration (FDA) defines two categories of FAA: (1) antimicrobial agents that have direct contact on food, and (2) antimicrobial agents used in water that have contact with food or used as food-contact substances. This definition is used to define antimicrobials which are used in food processing for commercial purposes (U.S. Food and Drug Administration, 1999). Following the definition of FAA by the FDA, Malaysia's Food Regulation 1985 (P.U.(A) 437/85) with the latest amendment (P.U. (A) 200/2017) defines FAA in regulation 20A as follows: any substance that (1) preserves food by hindering or reducing microorganisms and spoilage growth including mould, fungi, and rope inhibitors or (2) sterilises polymeric food-contact surfaces (P.U.(A) 437/85 Food Regulations 1985, 2017).

The selection of FAA is based on its natural and synthetic origins besides considering whether it is safe for consumption. Natural FAA such as antimicrobial peptides (APs) of animal origins have received interest due to the following: (1) their innate immunity mechanism in animals (Palmieri et al., 2018); and (2) its function to replace toxic chemical-synthesis FAA is cancerous to human (Pisoschi et al., 2018). Natural FAA has been associated with relieving and avoiding cancer, ageing, and cardiovascular diseases (Von Borowski et al., 2018). Various studies determined the toxicity level of animal antimicrobials by examining their $\mathrm{LC}_{50}$ (Fink et al., 2020) and FAA of animal origins such as lactoferrin and chitosan that were approved and generally recognised as safe (GRAS) by the FDA due to their potent metabolites in inhibiting pathogenic bacteria (Rees et al., 2017). Besides its natural origin and safety for consumption, FAA should fulfil these characteristics: broad antimicrobial capability spectrum, kill rather than inhibit food pathogens, potent at low concentration, thermally labile and stable at $\mathrm{pH}$ changes (Pisoschi et al., 2018).

\section{Halal Food Antimicrobial Agents}

Halal is an Arabic word that indicates a state of permissibility for objects, actions and consumption following the Shariah law (Department of Standards Malaysia, 2019) provided that they are safe and not toxic. Surah al-Baqara verse 168 in the al-Quran states, "O mankind, 
eat from whatever is on earth that is lawful and good" (al-Quran 2:168). In another verse, alBaqara verse 173, Allah SWT states: "He has forbidden to you dead animals, blood, the flesh of swine that have been dedicated to other than Allah SWT" (al-Quran 2:173). These verses express the virtuous commandment by referring to the terms of halal and toyyib in food consumption. From these verses, pigs and dogs are prohibited as there is evidence of reducing the quality life of human after consuming pork or having some physical contact with dogs. For instance, pork has a 7.6 ratio of omega-6/omega-3 fatty acids (Ojha et al., 2017) which can increase the risk of cardiovascular, autoimmune, cancer, and inflammatory diseases (Leung et al., 2019). Dogs are linked to diseases from parasites and pathogens such as Campylobacteriosis (Skarp, Hänninen \& Rautelin, 2016). Thus, for an FAA to be acknowledged as HFAA, it should not contain ingredients from these sources and derivatives.

The Malaysian Standard MS 1500:2019 halal food, which is the general guidelines from the Department of Standards Malaysia (DSM), states that halal foods should not contain najs which refers to pigs, dogs and their descendants besides free from poison, intoxication and hazardous materials including contamination from foodborne pathogens during preparation, processing, handling, packaging, storage and distribution. DSM mentioned that halal foods should originate from slaughtered animals according to the Shariah law (Department of Standards Malaysia, 2019). Thus, the FAA should conform to the Malaysian Standard MS 1500:2019 as the status of the FAA may hinder this confirmatory. For instance, APs from lactoperoxidase from pigs (Pisoschi et al., 2018) and caprylic acid from human breast milk do not conform to MS 1500:2019.

\section{Animal Source of Antimicrobial Agents}

Natural antimicrobials can be found in animals, plants, and bacteria. Some examples of animal origins are lysozyme in milk and chitosan in seafood (Pisoschi et al., 2018). Natural antimicrobials derived from plants such as saponins, eugenol, carvacrol, linalool, citral, terpene, flavonoids, and thymol are obtained from various parts of plants such as tea, basil leaves, onions, ginger, cloves, parsley seeds and fruits. The Gram-positive bacterium also produces cationic and APs that can penetrate small-sized membranes which have antimicrobial effects on various foodborne pathogenic microorganisms. For example, the Lactobacillus species is isolated from fermented food to produce one of the active AP groups known as bacteriocin.

FAA from the animal source originates from the defence systems of animals. For example, lactoferrin and lysozyme can be found in eggs and milk from mammals, which are among the food antimicrobials that originate from animals (Shi et al., 2018). Lactoferrin can be extracted from human milk (Novoselova \& Prosekov, 2016) and found in white blood cells, saliva, and tears (Franco, et al., 2018). Other APs can be derived from animal sources such as chitosan, pleurosidine, and spheniscin which have antimicrobial properties (Pisoschi et al., 2018). 


\section{Lactoferrin}

Lactoferrin is a glycoprotein-iron compound that has a strong affinity to iron. This chelating compound renders iron deficiency to bacteria, fungi and parasite cells (Zhang et al., 2017). Lysozyme is an enzyme that breaks the peptidoglycan bonds of bacterial cell walls. Grampositive bacteria have these bonds, and they are susceptible to lysozyme inhibitory (Franco et al., 2018). To obtain lactoferrin, skim milk is diluted with dilution buffer and incubated overnight with stationary, packed into a column. The lactoferrin is eluted with elution buffer using cation exchange chromatography. The reverse micellar extraction is another method to obtain lactoferrin from milk (Pawar et al., 2019).

\section{Chitosan}

Chitosan is a deacetylated chitin that is produced from crustacean shells such as shrimp, crab and crayfishes. The chemical name of chitosan is 2-amino-2-deoxy-b-D-glucan that renders the potent inhibitory effect in medical and agricultural industries due to its cationic structure (Khare, Biswas \& Sahoo, 2014). Different chitosan sources have different molecular weight, deacetylation grade, and emulsion abilities from the chitosan of a crab shell. The chitosan's molecular weight, length, deacetylation levels, and the replacement position of glucosamine chitosan units, $\mathrm{pH}$ chitosan solution, and target organisms can affect its inhibitory efficacy (Salama et al., 2020).

\section{Pleurocidin}

Pleurocidin from the skin of winter flounder fish (Pleuronectes americanus) is a polypeptide of 25 amino acids. The mucosal tissues and myeloid cell of the fish skin produce high content of pleurocidin (Gyawali \& Ibrahim, 2014) that act as a defence system by inhibiting the growth of pathogenic microorganisms that infect fish and a physical barrier against climatic change. Pleurocidin can be used as halal food antimicrobial due to its stability and tolerance against heat and salt besides its noncytotoxicity to human cells and potency against food pathogens such as L. monocytogenes, $P$. expansum, V. parahemolyticus, S. cerevisiae, and E. coli O157: H7. The ability of dissolved pleurocidin in saliva with a salivary enzyme can inhibit biofilm generation of cariogenic bacteria such as $S$. mutans. The incorporation of pleurocidin in food can ensure food safety and prevent dental caries (Sun et al., 2017). However, its efficacy is inhibited in a rich-bivalent-ion environment, such as magnesium and calcium solutions.

\section{Free fatty acids}

Fatty acids are carbon chain that consists of a carboxyl group $(-\mathrm{COOH})$ and a methyl group $\left(-\mathrm{CH}_{3}\right)$ at both ends. The hydrophilicity of the carboxyl group and the hydrophobicity of the methyl group contribute to the amphipathic characteristics of the fatty acids. Fatty acids can be found in mammals' milk such as cows, camels, goats, buffaloes, sheep (Claeys et al., 2014), horse, yak, reindeer and donkey (Martini et al., 2014) which are dairy-species mammals 
that produce milk (Alichanidis et al., 2016). The milk from these animals is halal and permitted for consumption (Department of Standards Malaysia, 2019).

Lipids from animals such as free fatty acids (FFA) have microbial inhibitory effects against a broad spectrum of pathogenic bacteria and fungi. Medium- and long-chain free fatty acids can deactivate L. monocytogenes (Sternkopf Lillebæk et al., 2017). Humans cannot synthesise EPA and DHA which have to be obtained from animal, plant, and bacterial sources as alternatives (Leung et al., 2019). FFA incorporates chitosan as an edible food coating to preserve food for better antimicrobial activity and decreasing the roughness of coating (Limited, 2012). Besides that, food manufacturers are interested in this incorporation to develop other food coatings using polysaccharide-based ingredients such as cellulose, starch, and dextrin (Zivanovic et al., 2014).

Fatty acids are generally classified as the following: (a) carbon chain: short fatty acid chain (SCFA) with < 6 carbons, medium fatty acids chain (MCFA) with $6<$ carbon $<12$ (Souza et al., 2014), and long-chain fatty acids (LCFA) with > 16 carbons; and (b) the existence or absence of double bond: unsaturated fatty acids if it contains one or more $\mathrm{C}=\mathrm{C}$ double bonds or saturated fatty acids if it contains only C-C bonds.

These antimicrobial activities of fatty acids are due to the presence of the carboxyl group $(-\mathrm{OH})$. On the other hand, methylated fatty acids normally appear in the form of fatty acid methyl esters (FAMES) which have fewer effective activities. In addition, SCFA such as butanoic acid (C4:0) and MCFA such as caproic (C6:0), caprylic (C8:0), and lauric acids (C12:0) exhibit stronger inhibitory activity than LCFA including palmitic (C16:0) and stearic acids (C18:0) (Souza et al., 2014). Davidson et al. (2015) mention that the carboxyl group reduces the acidification of the intercellular cell and interferes with the protein membranes of pathogenic bacteria due to the small amount of carbon in SCFA. Hence, SCFA and MCFA have been widely used as antimicrobials in food such as infant formula, pharmaceutical and medical applications (Rodriguez-Moya \& Gonzalez, 2015).

Bond type is another factor that contributes to the antibacterial activities of fatty acids. At the same carbon chain length, unsaturated fatty acids with a double bond of carbon chain have a stronger inhibitory effect than saturated fatty acids. The unsaturated SCFA and MCFA are more sensitive to Gram-positive than Gram-negative bacteria. Among the monounsaturated fatty acids, the 14 and 16 carbon chains have a higher potency than other fatty acids in the same group. The double bond of unsaturated fatty acids, which is attributed to the cis formation, had shown stronger antibacterial activity than trans formation because the latter had a similar structure of saturated fatty acids.

\section{Challenges of Halal Food Antimicrobials}

The APs from the animal origin of antimicrobials is another issue for the halal concept. Although they have active inhibiting property, the source of APs is extracted from the 
gastrointestinal secretory fluids of rats and pigs which contradict the halal requirement for food antimicrobials (Department of Standards Malaysia, 2009). Due to the limited information and lack of awareness, consumers accept these APs as food preservatives without knowing the origin of these antimicrobials.

It is not permissible for Muslims regardless of the methods used to isolate and purify antimicrobials from humans (Department of Standards Malaysia, 2019). For instance, caprylic acid from human breast milk and acid purification of human lactoferrin from bovine milk by the transgenic bovine species contain human's lactoferrin transgene (Novoselova \& Prosekov, 2016). Lactoferrin that uses human recombinant (HR) or genetically-modified (GMO) techniques are not permissible. The reason for the prohibition of human sources is stated in the al-Quran and al-Sunnah in which humans are the caliph in this world that should be respected and they have dignity. Al-Israa' 17:70, al-Quran states: "Verily We have honoured the children of Adam. We carry them on land and sea, and have made provision of good things for them, and have preferred them above many of those whom We created with a marked preferment." Al-An'am 6:145, al-Quran mentions: "Say (O Muhammad): I find not in that which is revealed unto me aught prohibited to an eater that he eats thereof, except it be carrion, or blood poured forth, or swine flesh for that verily is foul or the abomination which was immolated to the name of other than Allah SWT. But who is compelled (thereto), neither craving nor transgressing, (for him) lo! Your Lord is Forgiving, Merciful." The Arabic structure of the word "whereof you eat' directly describes that humans can only consume the meat of livestock and not humans, either internal or external parts.

Generally, the halal status of ingredients produced by HR and GMO is based on two opinions: a) the Shafie school of thought that considers it as not permissible due to the prohibition of consuming ingredients from human source (Department of Standards Malaysia, 2019); and (b) it is permissible since the nature of the antimicrobials source (milk) has changed into different properties and characteristics of substance (lactoferrin). The nature of change in the latter opinion is called al-istihalah (Yunos et al., 2014). Istihalah is defined as the transformation or conversion from one substance to another substance. From the Shafie school of thought, it is only applicable after completing the transformation (Istihalah al-Kamilah).

However, the Department of Islamic Development Malaysia (JAKIM) opts for the former opinion as there is another permissible method that extracts bovine lactoferrin by microfiltration and adsorption through a strong cation exchanger (Burling, 2018).

\section{Generally Recognised as Safe (GRAS) and Content Limit of Food Antibacterial Agents}

The concept of halal is not only confined to permitted food, but also its nutritious value and safety for consumption. This concept has led to the broader halal purpose in which halal and toyyiban involve two elements; halal means are justified by Shariah while toyyiban means safe, healthy, nutritious, and good quality (Sowhini et al., 2020). Toyyiban aspect applies to safe and food that is non-contaminated with microorganisms. It considers the degree of toxicity 
of antibacterial preservatives that are mixed into the food. The increase in resistance of a pathogenic microorganism to antibiotics and the use of natural preservatives in food and storage companies have led to the use of natural preservatives such as the FAA. However, the safety of natural preservatives such as the FAA has resulted in accredited bodies such as the European Union Commission (EUC) and the United States Food and Drug Administration (FDA) to produce safeguard lists. The EUC has listed FAA in Everything Added to Food in the US (EAFUS) list, where the FDA recognises these ingredients as safe for use FAA (GRAS). For instance, antimicrobials from milk such as lactoferrin are accepted as FAA in the USA and its maximum allowable limit depends on the type of food system. For yoghurt and powdered milk, the maximum allowable limit is $1 \mathrm{mg} / \mathrm{g}$ and $4 \mathrm{mg} / \mathrm{g}$, respectively. The EU has set the maximum allowable limit for additional food systems such as candies $(7.5 \mathrm{mg} / \mathrm{g})$, cheese (20 $\mathrm{mg} / \mathrm{g})$, non-alcoholic drinks (1.20 mg/g), cake and pastries $(10 \mathrm{mg} / \mathrm{g})$ (Franco et al., 2018).

Chitosan has also been recognised as GRAS as mentioned by the FDA through GRAS notification no. GRN 000443 for shrimp-derived chitosan and GRN 000397 for chitosan from Aspergillus niger. Negligible information is available on the maximum allowable chitosan in food. The FDA has also provided the maximum level of chitosan in drinking water which is 10 $\mathrm{mg} / \mathrm{L}$. Although the FFA received GRAS status, the FDA has declared trans-fatty acids as harmful for consumption (U.S. Food and Drug Administration, 2018). The EUC and FDA have not reported the maximum use level of individual FFA in food except for erucic acid or unsaturated omega-9 fatty acid. However, the German Federal Institute for Risk Assessment (BfR) has proposed the maximum use level of $20 \mathrm{~g} / \mathrm{kg}, 4 \mathrm{~g} / \mathrm{kg}$, and $30 \mathrm{~g} / \mathrm{kg}$ of erucic acid in vegetable oils and fats, infant and follow-on formula, and mustard, respectively (German Federal Institute for Risk Assessment [BfR], 2018). The EUC proposed the values for the maximum-level recommendation (Knutsen et al., 2016).

\section{Toxicity}

The application of the FAA dose should be based on the maximum use level and toxicity value to comply with the manufacturing of halal and toyyiban food products and reduce the adverse effects on consumers (Sowhini et al., 2020). Repeat-dose toxicity, genotoxicity, and carcinogenicity information have become the threshold for food application (Feigenbaum \& Worth, 2019). Carcinogen is a substance that induces (malignant) tumours, increases the incidence of malignancy, and shortens the time of tumour occurrence after its inhalation, ingestion, dermal application, or injection (Corvi, Spielmann \& Hartung, 2019). Genotoxicity is the toxicity effect from the interaction of the carcinogen that renders DNA damage. Repeatdose toxicity addresses the type of effect and its degree by the carcinogen via repetitive assays (Doe \& Botham, 2019).

The European Food Safety Authority (EFSA) revealed that lactoferrin which was injected into a rat at 2,000 mg/kg body weight per day had no adverse effect (European Food Safety Authority, 2012). Besides that, $0.4 \%$ of chitosan may render significant toxicity to human cells (Ma et al., 2018). Information regarding the toxicity of pleurocidin is limited; however, 
pleurocidin renders the toxicity value of $128 \mu \mathrm{g} / \mathrm{mL}$ towards HL60 human leukaemia cells and acute toxicity (after 1 hour) towards zebrafish embryos at $25 \mu \mathrm{g} / \mathrm{mL}$ concentration. In terms of safety, caprylic acid is approved and recognised as a GRAS compound by the FDA. Although the concentrations of FFA may be high in food, they exhibited low toxicity. Souza et al. (2014) revealed that the majority of fatty acids have more than $80 \%$ cell viability at their MIC concentrations. There was also a generic report on the toxicity of saturated and unsaturated FFA to human melanoma cell lines. Besides that, a study on the toxicity of individual FFA provided the details. Linoleic, arachidonic, palmitoleic, and palmitic acids at $200 \mu \mathrm{M}$ concentration exerted toxicity to human melanoma cells.

\section{Organoleptic Issues}

Organoleptic issues revealed that the quality of food taste should be maintained although the FAA can suppress bacterial growth. The high content of unsaturated FFA makes it prone to oxidation and cause rancidity in the food system. Unsaturated FFA with more double bonds is also susceptible to oxidation. For instance, C18:3 oxidises twice as fast as C18:2 (Caballero, Finglas \& Toldra, 2016). Food that is mixed with herbs and spices should not disturb the taste. A mixture of oregano oils on meat and fish does not change the taste because the taste of meat mixed with $0.8 \% \mathrm{v} / \mathrm{w}$ oregano oil after cooking and left to be cooled at $5{ }^{\circ} \mathrm{C}$ is acceptable. The flavour, smell, and colour of minced meat can be improved when adding $1 \%$ of the oregano oil after cooking.

Seafood products can be preserved with oregano oil and thyme besides meat products. For example, cod fillet produces a different but pleasant taste when it is mixed with $0.05 \%(\mathrm{v}$ $/ \mathrm{w})$ oregano oil, while thyme mixed with Asian fishes of $0.05 \%(\mathrm{v} / \mathrm{v})$ could preserve the fish up to 33 days at $0-2{ }^{\circ} \mathrm{C}$. Adding thyme oil by $0.9 \%$ in cooked shrimp did not show any effect on taste and appearance. However, the accepted taste and appearance of the shrimp can be reduced if $1.8 \%$ of thyme oil is used as a coating.

Most essential oil components are approved as FAA and flavours. For example, carvacrol can produce spicy-like scents, citral-like lemons, and geraniol-like roses. The exposure of 1 $\mathrm{mM}$ carvacrol or cinnamic acid to kiwi fruit and milk melon can delay the defects without causing organoleptic changes. However, essential oils are seldom used in food as the FAA is very limited due to the consideration of taste, despite the fact that the majority of essential oils are classified as GRAS. 
Table 1: Food antimicrobial agents

\begin{tabular}{|c|c|c|c|c|c|c|c|}
\hline \multirow{2}{*}{$\begin{array}{l}\text { Animal source } \\
\text { of antimicrobial } \\
\text { agent }\end{array}$} & \multirow[t]{2}{*}{ Possible source } & \multirow{2}{*}{$\begin{array}{l}\text { 1) Halal and 2) } \\
\text { toyyiban status }\end{array}$} & \multirow{2}{*}{$\begin{array}{l}\text { Maximum use level in the } \\
\text { food system }\end{array}$} & \multicolumn{3}{|l|}{ Toxicity value } & \multirow{2}{*}{$\begin{array}{l}\text { Organoleptic } \\
\text { limit }\end{array}$} \\
\hline & & & & Carcinogenicity & Genotoxicity & $\begin{array}{l}\text { Repeat-dose } \\
\text { toxicity }\end{array}$ & \\
\hline Lactoferrin & $\begin{array}{l}\text { 1) Eggs from mammals } \\
\text { 2) Milk, white blood } \\
\text { cells, saliva, and tears } \\
\text { from mammals, } \\
\text { including human }\end{array}$ & $\begin{array}{l}\text { 1) Not halal if the } \\
\text { sources are from } \\
\text { human and non- } \\
\text { halal animals } \\
\text { 2) Approved as } \\
\text { GRAS }\end{array}$ & $\begin{array}{l}\text { 1) Yoghurt }(1 \mathrm{mg} / \mathrm{g})(\mathrm{FDA}) \\
\text { 2) Powdered milk (4 mg/g) } \\
\text { (FDA) } \\
\text { 3) Infant formulae }(1 \mathrm{mg} / \mathrm{g}) \\
\text { (FDA) } \\
\text { 4) Milk dessert }(2 \mathrm{mg} / \mathrm{g}) \\
\text { (FDA) } \\
\text { 5) Chewing gum }(30 \mathrm{mg} / \mathrm{g}) \\
\text { (FDA) }\end{array}$ & No report & $\begin{array}{l}>2000 \mathrm{mg} / \mathrm{kg} / \mathrm{day} \text { on } \\
\text { rats (Yamauchi } \text { et } \\
\text { al., 2000) }\end{array}$ & $\begin{array}{l}>1800 \mathrm{mg} / \mathrm{kg} / \mathrm{day} \\
\text { on rats }(\text { Cerven, } \\
\text { DeGeorge \& } \\
\text { Bethell, 2008) }\end{array}$ & No report \\
\hline Chitosan & $\begin{array}{l}\text { Crustaceans such as } \\
\text { shrimp, crab, and } \\
\text { crayfishes }\end{array}$ & $\begin{array}{l}\text { 1) Halal } \\
\text { 2) Approved as } \\
\text { GRAS }\end{array}$ & $\begin{array}{l}\text { Drinking water }(10 \mathrm{mg} / \mathrm{L}) \\
\text { (FDA) }\end{array}$ & $\begin{array}{l}16 \mathrm{~g} / \mathrm{kg} \text { on rats } \\
\text { (Health \& } \\
\text { Services, 1997) }\end{array}$ & No report & $\begin{array}{l}2,545 \mathrm{mg} / \mathrm{kg} / \mathrm{day} \\
\text { on rats (National } \\
\text { Institutes of } \\
\text { Health \& US } \\
\text { Department of } \\
\text { Health and } \\
\text { Human Services, } \\
\text { 2017) }\end{array}$ & $\begin{array}{l}\text { Chitosan is } \\
\text { tasteless, and } \\
\text { the report of } \\
\text { organoleptic } \\
\text { limit is absent }\end{array}$ \\
\hline Pleurocidin & $\begin{array}{l}\text { The skin of winter } \\
\text { flounder fish } \\
\text { (Pleuronectes } \\
\text { americanus) }\end{array}$ & $\begin{array}{l}\text { 1) Halal } \\
\text { 2) No report of } \\
\text { GRAS status }\end{array}$ & No report & No report & No report & No report & No report \\
\hline Free fatty acid & $\begin{array}{l}\text { Milk of mammals, } \\
\text { including human }\end{array}$ & $\begin{array}{l}\text { 1) Halal if the } \\
\text { sources are from } \\
\text { halal animals Not } \\
\text { permissible if the } \\
\text { source is from } \\
\text { human } \\
\text { 2) Fatty acids are } \\
\text { approved as GRAS } \\
\text { except for trans- } \\
\text { fatty acids }\end{array}$ & $\begin{array}{l}\text { 1) Erucic acid in: } \\
\text { a) Vegetable oils and fats } \\
(0.002 \mathrm{mg} / \mathrm{kg})(\mathrm{BfR}) \\
\text { b) Infant and follow-on } \\
\text { formula }(0.004 \mathrm{mg} / \mathrm{kg}) \\
\text { (BfR) } \\
\text { c) Mustard }(0.03 \mathrm{~g} / \mathrm{kg}) \\
\text { (BfR) }\end{array}$ & $\begin{array}{l}200 \mu \mathrm{M} \text { of linoleic, } \\
\text { arachidonic, } \\
\text { palmitoleic, and } \\
\text { palmitic acids } \\
\text { (human melanoma } \\
\text { cells) }\end{array}$ & No report & No report & $\begin{array}{l}\text { Unsaturated } \\
\text { FFA causes } \\
\text { rancidity; } \\
\text { however, no } \\
\text { organoleptic } \\
\text { limit is reported }\end{array}$ \\
\hline
\end{tabular}




\section{Conclusion}

The concept of halal and toyyiban should be viewed holistically in nutrition, including the addition of FAA into food products during the manufacturing process. More detailed studies are needed to find appropriate preservation techniques to improve safety and quality without causing nutrient loss in food. In this context, natural FAA has received considerable attention for the benefit of food quality and safety besides reducing the adverse effects on human health. Furthermore, natural FAA promotes acceptable criteria for food quality retention. Various experiments involving essential oils, enzymes, bacteriocin, chitosan, and organic acids on different types of foods have proven that they are suitable for antimicrobial inhibitors. They are also valid and accepted as synthetic FAA. However, more detailed studies are needed to find new sources of FAA, including FAA from animal sources. The concept of toyyiban should be included in the nutritional aspect. Hence, it is crucial to study the FAA levels of toxicity and limitations to avoid health issues since the food should be not only halal but also safe.

\section{Conflict of Interest}

We declare that we have no conflict of interest.

\section{Acknowledgement}

This work was supported by the Malaysia Fundamental Research Grant Scheme (FRGS19-041- 0649 or FRGS/1/2018/STG04/UIAM/03/1) of the Ministry of Higher Education Malaysia.

\section{Reference}

Alichanidis, E., Moatsou, G., \& Polychroniadou, A. (2016). Composition and properties of non-cow milk and products. In Non-Bovine Milk and Milk Products (pp. 81-116). Elsevier Inc. https://doi.org/10.1016/B978-0-12-803361-6.00005-3

Azilawati MI, Hashim DM, Jamilah B, et al. (2015). RP-HPLC method using 6-aminoquinolyl-N-hydroxysuccinimidyl carbamate incorporated with normalization technique in principal component analysis to differentiate the bovine, porcine and fish gelatins. Food Chemistry, 172, 368-376. DOI:10.1016/J.Foodchem.2014.09.093.

Aziz, S. A., Musa, R., \& Rahman, S. A. (2016). Theorizing Islamic retail experiential value in predicting total Islamic experience quality: A hypothesised model. Procedia Economics and Finance, 37(16), 453-459. https://doi.org/10.1016/S2212-5671(16)30151-4

Barłowska, J., Szwajkowska, M., \& Litwi, Z. (2011). Nutritional value and technological suitability of milk from various animal species used for dairy production. Comprehensive Reviews in Food Science and Food Safety, 10, 291-302. https://doi.org/10.1111/j.15414337.2011.00163.x

Błaszczyk, I. (2019). The management of food safety in beverage industry. In A. M. Grumezescu \& A. M. Holban (Eds.), Safety Issues in Beverage Production Volume 18: The Science of Beverages (1st ed., pp. 1-38). Elsevier Inc. https://doi.org/10.1016/B978-0-12816679-6.00001-2

Burling, H. (2018). Process for extracting pure fractions of lactoperoxidase and lactoferrin from milk serum.

Caballero, B., Finglas, P. M., \& Toldra, F. (2016). Encyclopedia of food and health.

Cerven, D., DeGeorge, G., \& Bethell, D. (2008). 28-Day repeated dose oral toxicity of recombinant human apo-lactoferrin or recombinant human lysozyme in rats. Regulatory Toxicology and Pharmacology, 51(2), $162-167$. https://doi.org/10.1016/j.yrtph.2008.03.007

Claeys, W. L., Verraes, C., Cardoen, S., et al. (2014). Consumption of raw or heated milk from different species: An evaluation of the nutritional and potential health benefits. Food Control, 42, 188-201. https://doi.org/10.1016/j.foodcont.2014.01.045

Corvi, R., Spielmann, H., \& Hartung, T. (2019). Alternative approaches for carcinogenicity and reproductive toxicity. In The History of 
Alternative Test Methods in Toxicology, 4(4). https://doi.org/10.1016/b978-0-12-813697-3.00024-x

Davidson, P., Cekmer, H. B., Monu, E., et al. (2015). The use of natural antimicrobials in food: An overview. In T. M. Taylor (Ed.), Handbook of Natural Antimicrobials for Food Safety and Quality (1st ed., pp. 49-68). Woodhead Publishing Limited. https://doi.org/10.1016/B978-1-78242-034-7.00003-7

Department of Standards Malaysia. (2019). Malaysian Standard MS 1500: 2019 Halal food - General requirements (Third revision).

Doe, J., \& Botham, P. (2019). Chemicals and pesticides: A long way to go. In The History of Alternative Test Methods in Toxicology (Issue 4). Elsevier Inc. https://doi.org/10.1016/b978-0-12-813697-3.00021-4

European Food Safety Authority. (2012). Scientific opinion on bovine lactoferrin. EFSA Journal, 10(5), 1-26. https://doi.org/10.2903/j.efsa.2012.2701.

Feigenbaum, A., \& Worth, A. P. (2019). Alternative approaches for the assessment of chemicals in Food. In The History of Alternative Test Methods in Toxicology. Elsevier Inc. https://doi.org/10.1016/b978-0-12-813697-3.00022-6

Fink, R., Wang, Z., Oder, M., et al. (2020). Balancing chemical function with reduced environmental health hazards: A joint probability approach to examine antimicrobial product efficacy and mammalian toxicity. Journal of Cleaner Production, 262, 121323. https://doi.org/10.1016/j.jclepro.2020.121323

Franco, I., Pérez, M. D., Conesa, C., et al. (2018). Effect of technological treatments on bovine lactoferrin: An overview. Food Research International, 106(July 2017), 173-182. https://doi.org/10.1016/j.foodres.2017.12.016

German Federal Institute for Risk Assessment (BfR). (2018). Erucic acid: BfR endorses proposed maximum levels, but foods with added fats should be restricted too. https://doi.org/10.17590/20190116-105459-0

Gyawali, R., \& Ibrahim, S. A. (2014). Natural products as antimicrobial agents. Food Control, 46, 412-429. https://doi.org/10.1016/j.foodcont.2014.05.047

Hashim, H. I. C., \& Shariff, S. M. M. (2016). Halal supply chain management training: Issues and challenges. Procedia Economics and Finance, 37(16), 33-38. https://doi.org/10.1016/S2212-5671(16)30089-2

Khare, A. K., Biswas, A. K., \& Sahoo, J. (2014). Comparison study of chitosan, EDTA, eugenol and peppermint oil for antioxidant and antimicrobial potentials in chicken noodles and their effect on colour and oxidative stability at ambient temperature storage. $L W T$ Food Science and Technology, 55(1), 286-293. https://doi.org/10.1016/j.lwt.2013.08.024

Knutsen, H. K., Alexander, J., Barregård, L., et al. (2016). Erucic acid in feed and food. EFSA Journal, 14(11), 1-173. https://doi.org/10.2903/j.efsa.2016.4593

Leung, H. H., Ng, A. L., Durand, T., et al. (2019). Increase in omega-6 and decrease in omega-3 polyunsaturated fatty acid oxidation elevates the risk of exudative AMD development in adults with Chinese diet. Free Radical Biology and Medicine, 145, 349-356. https://doi.org/10.1016/j.freeradbiomed.2019.10.007

Limited, W. P. (2012). Emerging food packing technologies: Principles and practice. In K. L. Yam \& D. S. Lee (Eds.), Semiconductor Nanowires. Woodhead Publishing Limited. https://doi.org/10.1016/B978-1-78242-253-2.09001-0

Ma, Z., Garrido-Maestu, A., Lee, C., et al. (2018). Comprehensive in vitro and in vivo risk assessments of chitosan microparticles using human epithelial cells and Caenorhabditis elegans. Journal of Hazardous Materials, 341, 248-256. https://doi.org/10.1016/j.jhazmat.2017.07.071

Martini, M., Altomonte, I., \& Salari, F. (2014). Amiata donkeys: Fat globule characteristics, milk gross composition and fatty acids. Italian Journal of Animal Science, 13(3118), 123-126. https://doi.org/10.4081/ijas.2014.3118

P.U.(A) 437/85 Food Regulations 1985, 1 (2017) (testimony of Ministry of Health Malaysia). http://www.albayan.ae

Mutalib, S. A., Muin, N. M., Abdullah, A., et al. (2015). Sensitivity of polymerase chain reaction (PCR)-southern hybridization and conventional PCR analysis for Halal authentication of gelatin capsules. LWT - Food Science and Technology, 63(1), 714-719. https://doi.org/10.1016/j.lwt.2015.03.006

National Institutes of Health, \& US Department of Health and Human Services. (2017). NTP technical report on the toxicity study of chitosan administered in feed to Sprague Dawley rats. National Toxicology Program, 93(93), 1-93. https://ntp.niehs.nih.gov/ntp/htdocs/st_rpts/tox093_508.pdf 
Novoselova, M. V., \& Prosekov, A. Y. (2016). Technological options for the production of lactoferrin. Foods and Raw Materials, 4(1), 90-101. https://doi.org/10.21179/2308-4057-2016-1-90-101

Ojha, K. S., Perussello, C. A., García, C. Á., et al. (2017). Ultrasonic-assisted incorporation of nano-encapsulated omega-3 fatty acids to enhance the fatty acid profile of pork meat. Meat Science, 132, 99-106. https://doi.org/10.1016/j.meatsci.2017.04.260

Palmieri, G., Balestrieri, M., Capuano, F., et al. (2018). Bactericidal and antibiofilm activity of bactenecin-derivative peptides against the food-pathogen Listeria monocytogenes: New perspectives for food processing industry. International Journal of Food Microbiology, 279(April), 33-42. https://doi.org/10.1016/j.ijfoodmicro.2018.04.039

Parfene, G., Horincar, V., Tyagi, A. K., et al. (2013). Production of medium chain saturated fatty acids with enhanced antimicrobial activity from crude coconut fat by solid state cultivation of Yarrowia lipolytica. Food Chemistry, 136(3-4), 1345-1349. https://doi.org/10.1016/j.foodchem.2012.09.057

Pawar, S. S., Iyyaswami, R., \& Belur, P. D. (2019). Selective extraction of lactoferrin from acidic whey using CTAB/n-heptanol reverse micellar system. Journal of Food Science and Technology, 56(5), 2553-2562. https://doi.org/10.1007/s13197-019-03738-1

Pisoschi, A. M., Pop, A., Georgescu, C., et al. (2018). An overview of natural antimicrobials role in food. European Journal of Medicinal Chemistry, 143, 922-935. https://doi.org/10.1016/j.ejmech.2017.11.095

Rees, C. E. D., Doyle, L., \& Taylor, C. M. (2017). Listeria monocytogenes. In Foodborne Diseases: Third Edition (3rd ed.). Elsevier Inc. https://doi.org/10.1016/B978-0-12-385007-2.00012-7

Rodriguez-Moya, M., \& Gonzalez, R. (2015). Proteomic analysis of the response of Escherichia coli to short-chain fatty acids. Journal of Proteomics, 122, 86-99. https://doi.org/10.1016/j.jprot.2015.03.033

Romi Mukherjee, S. (2014). Global Halal: Meat, money, and religion. Religions, 5(1), 22-75. https://doi.org/10.3390/rel5010022

Salama, A., Hasanin, M., \& Hesemann, P. (2020). Synthesis and antimicrobial properties of new chitosan derivatives containing guanidinium groups. Carbohydrate Polymers, 241, 116363. https://doi.org/10.1016/j.carbpol.2020.116363

Shi, P., Liu, M., Fan, F., et al. (2018). Identification and mechanism of peptides with activity promoting osteoblast proliferation from bovine lactoferrin. Food Bioscience, 22(September 2017), 19-25. https://doi.org/10.1016/j.fbio.2017.12.011

Skarp, C. P. A., Hänninen, M. L., \& Rautelin, H. I. K. (2016). Campylobacteriosis: The role of poultry meat. Clinical Microbiology and Infection, 22(2), 103-109. https://doi.org/10.1016/j.cmi.2015.11.019

Soon, J. M., Chandia, M., \& Regenstein, J. Mac. (2017). Halal integrity in the food supply chain. British Food Journal, 119(1), 39-51. https://doi.org/10.1108/BFJ-04-2016-0150

Souza, J. L. S., Da Silva, A. F., Carvalho, P. H. A., et al. (2014). Aliphatic fatty acids and esters: Inhibition of growth and exoenzyme production of Candida, and their cytotoxicity in vitro: Anti-Candida effect and cytotoxicity of fatty acids and esters. Archives of Oral Biology, 59(9), 880-886. https://doi.org/10.1016/j.archoralbio.2014.05.017

Sowhini, N. S. H. A., Sani, M. S. A., Hashim, Y. Z. H.-Y., et al. (2020). Antibacterial test and toxicity of plant seed extracts: A review. Food Research, 4, 12-27.

Sternkopf Lillebæk, E. M., Lambert Nielsen, S., Scheel Thomasen, R., et al. (2017). Antimicrobial medium- and long-chain free fatty acids prevent PrfA-dependent activation of virulence genes in Listeria monocytogenes. Research in Microbiology, 168(6), 547557. https://doi.org/10.1016/j.resmic.2017.03.002

Sun, E., Belanger, C. R., Haney, E. F., et al. (2017). Host defense (antimicrobial) peptides. In Peptide Applications in Biomedicine, Biotechnology and Bioengineering. Elsevier Ltd. https://doi.org/10.1016/B978-0-08-100736-5.00010-7

U.S. Food and Drug Administration. (2018). Final determination regarding partially hydrogenated oils. U.S. Food and Drug Administration.

Von Borowski, R. G., Macedo, A. J., \& Gnoatto, S. C. B. (2018). Peptides as a strategy against biofilm-forming microorganisms: Structure-activity relationship perspectives. European Journal of Pharmaceutical Sciences, 114(November 2017), 114-137. https://doi.org/10.1016/j.ejps.2017.11.008

Yunos, R. M., Mahmood, C. F. C., \& Mansor, N. H. A. (2014). Understanding mechanisms to promote halal industry-The stakeholders' views. Procedia - Social and Behavioral Sciences, 130, 160-166. https://doi.org/10.1016/j.sbspro.2014.04.020 
Zhang, J. L., Han, X., Shan, Y. J., et al. (2017). Effect of bovine lactoferrin and human lactoferrin on the proliferative activity of the osteoblast cell line MC3T3-E1 in vitro. Journal of Dairy Science, 1-7. https://doi.org/10.3168/jds.2017-13161

Zivanovic, S., Davis, R. H., \& Golden, D. A. (2014). Chitosan as an antimicrobial in food products. In Handbook of Natural Antimicrobials for Food Safety and Quality. https://doi.org/10.1016/B978-1-78242-034-7.00008-6 